\title{
Performance evaluation of gravity fed inline drip irrigation system
}

B. L. Ayare and R. T. Thokal

Received : $12.01 .2018 ;$ Revised : 12.02.2018; Accepted : 21.02.2018

See end of the Paper for authors' affiliation

Correspondence to :

B.L. Ayare

Department of Soil and Water Conservation Engineering,

College of Agricultural Engineering and Technology, Dr. B.S.K.K.V., Dapoli, Ratnagiri (M.S.)

India

Email : blayare@yahoo.co.in
- ABSTRACT : The field experiment was under taken on research farm of College of Agriculture Engineering and Technology, Dapoli, dist.- Ratnagiri (M.S.) to evaluation the performance of gravity fed inline drip irrigation system for cashew plantation. The system used inline drippers having the average discharge of $0.6 \mathrm{lit} / \mathrm{hr}$. The design was done for $1 \mathrm{ha}$. area. The sizes (diameter) of the main line, sub main, lateral was computed as $40 \mathrm{~mm}, 12 \mathrm{~mm}$ and $6 \mathrm{~mm}$, respectively, which was found to be less as compared to the conventional drip irrigation system. The emission uniformity of gravity fed inline drip irrigation system was found to be 85 per cent and was good for tested emitters as per ASAE interpretation. The vertical and radial movement of moisture was observed upto $60,46 \mathrm{~cm}$ for $6 \mathrm{hrs}$ and $80,50 \mathrm{~cm}$ for $12 \mathrm{hrs}$, respectively which showed that the movement of moisture contour was faster in 6 hrs. as compared to $12 \mathrm{hrs}$. The moisture distribution pattern in gravel sandy loam lateritic soils showed that, the vertical movement of water was predominant than the lateral movement. The gravity fed inline drip irrigation system was found to be beneficial to small and marginal farmers of Konkan region of Maharashtra to provide the irrigation in remote areas.

- KEY WORDS : Gravity fed drip irrigation, Design, Moisture distribution, Cost

- HOW TO CITE THIS PAPER : Ayare, B.L. and Thokal, R.T. (2018). Performance evaluation of gravity fed inline drip irrigation system. Internat. J. Agric. Engg., 11(1) : 79-83, DOI: 10.15740/HAS/ IJAE/11.1/79-83. 